\title{
International Conference on Folk Dancing
}

$\mathrm{T}$ HE conference on folk dancing which formed part of the proceedings of the International (European) Folk Dance Festival, held in London on July 15-20 under the auspices of the English Folk Dance Society and the British National Committee on Folk Arts, met at Cecil Sharp House, Regent's Park, London, under the chairmanship of Prof. John L. Myres. One session was held at the Phœnix Theatre, Charing Cross Road, for the exhibition of cinematograph films and lantern slides illustrating the Morris and kindred dances and Dutch traditional dances.

The communications submitted to the conference numbered fifteen. It was thus possible, by adhering more or less closely to a fixed time-table, to allow ample opportunity for discussion and illustration by dance displays. The majority of the papers were concerned with the description of specific forms of national or regional dances; one by Mr. Rodney Gallop dealt with the principles and methods of recording folk dances, and the remainder discussed on broader lines questions of interpretation arising out of the comparative study of the dance as a popular mode of emotional and æsthetic expression among European peoples.

Of the communications of a more general character, that with which the conference opened, by Dr. Elise van der Ven Ten (Netherlands), on some aspects of the folk dance in various stages of the development of folk art, with the discussion which followed, was of importance for its clear-cut formulation of the relation between the scientific study of the folk dance and the revival of folk dancing as a means of individual, social and national expression. The author classified the folk dances of Europe according to the place they now fill in the life of the people, pointing out that while in eastern Europe they are still a living form of art, in central Europe they are dying, or even, as in modern Germany, have virtually become extinct; but in north-western Europe they are a revived art, largely owing to the work of Cecil Sharp (of which an account was given by Mr. Douglas Kennedy, director of the English Folk Dance Society, at a later stage of the conference).

It was laid down as a definite principle by Dr. van der Ven Ten and also by speakers in the discussion which followed the paper, that scientific study of the forms of the dance and its significance in the life of the folk is an essential condition of successful revival. Both in Germany and in Sweden, it was pointed out, such study had been found the essential preliminary in the revival of forms of the dance which would give full play to the development of individual and national consciousness.

Dr. Curt Sachs (Paris), in dealing with the symbolism of the dance, also stressed the importance in folk dance revival of study of the meaning or purpose of the primitive dance, which survives in the folk dance, although forgotten. The primitive dance, not being entirely æsthetic in origin, is on one hand a response to an internal physiological and psychological urge which raises the performer to an ecstatic magical plane, while externally its forms and associa- tions with material symbols, such as the garland and the bridge, by mimicry or representation lead symbolically to a culmination in the promotion of fertility.

Among communications dealing with national or regional forms of the dance, such as that, for example, by Mlle. Louise Witzig (Zurich) on the Swiss folk dance and its significance in the revival of rural culture, and Prof. Césara Ehrenkreutz-Jedrzejewiczkowa on Polish wedding customs, reference was made to the reciprocal borrowing between court and peasantry. Such borrowing was also shown by Miss Violet Alford to have affected the character of the Morris dance. In her study of the Morris and the Morisca, she argued that before the Morris was affected by the fashion for the Moors, which was responsible for the dancers' black faces, and before the name 'Morisca', or 'Morris', was applied to it, it had once belonged to a pre-Christian European group of dances which were connected with a sacred animal.

An alternative view of the origin of the sword and stick dances, to which Miss Alford had referred, was put forward by Dr. Richard Wolfram (Vienna), who, elaborating from extended observation, especially in South Germany, a theory propounded four years ago, argued that these and associated 'chain dances' are a dramatisation of an initiation ceremony. He relied largely on the evidence of the association of such dances with secret societies; but, in the discussion which followed, reluctance was shown to accept his views as an exclusive or generally applicable interpretation, while a further obstacle to acceptance was the fact that there is no evidence in initiatory rites of the seasonal element inseparable from the sword and cognate dances.

Among the numerous points of interest which emerged from the communications of a more purely descriptive character, reference can be made here to one or two only-such, for example, as the relation between music, song and dance in Norway (Dr. O. M. Sandvik, Oslo), the primitive magic of the hobby horse of the Calušari of Rumania (Prof. R. Vuia, Cluj), and the taboos on partnership in the dance between certain individuals, varying with the stage of the proceedings, in the dances which accompany the wedding ceremonies of Poland, as described in the communication to which reference has been made above. A remarkable cycle of folk dances from Holland and the rites with which they are associated was shown in a cinematograph film by Dr. D. J. van der Ven. These ranged from children's processional customs to obsolescent dances now performed only by the older folk in keeping up the practices of their younger days, and to the living customs of the Harvest Home, or the midsummer bonfire and accompanying battle, or the remarkable and characteristic Dutch feat of 'flag waving', a combination of calisthenics and juggling, which on account of its associations with folk festivals, as well as its action, may well link up, as Dr. van der Ven maintains, with the fertility magic of the other peasant customs which he described. 